Utah State University

DigitalCommons@USU

\title{
Effect of cold storage on development of suckers on aspen root cuttings
}

George A. Schier

R.B. Campbell

Follow this and additional works at: https://digitalcommons.usu.edu/aspen_bib

Part of the Forest Sciences Commons

\section{Recommended Citation}

Schier, George A. and Campbell, R.B., "Effect of cold storage on development of suckers on aspen root cuttings" (1978). Aspen Bibliography. Paper 4742.

https://digitalcommons.usu.edu/aspen_bib/4742

This Report is brought to you for free and open access by the Aspen Research at DigitalCommons@USU. It has been accepted for inclusion in Aspen Bibliography by an authorized administrator of DigitalCommons@USU. For more information, please contact

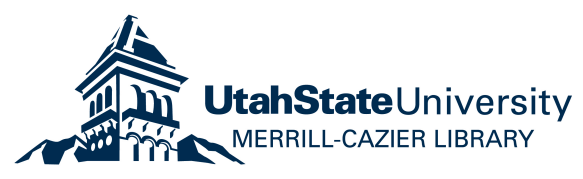


This study was to determine the effect of cold storage on sucker production from root cuttings taken from 10 aspen clones. Roots were collected in spring, summer, and fall and stored for vaxious periods in a cold room. Suckering from stored roots was compared with suckering from roots planted immediately after they were collected.

\section{METHODS}

Root segments were collected from 10 clones in Logan Canyon, east of Logan, Utah, on June 1 (2 weeks after bud break), August 9, and October 12 (after leaf fa11), 1976. After the roots were collected they were rinsed, cut into 8 by 1 to $2 \mathrm{~cm}$ segments, and soaked for 30 minutes in an aqueous slurry of 0.1 percent benomyl, a systemic fungicide. Segments from each clone were randomly divided into five groups of eight segments each. One group (contro1) was planted immediately, and the other four groups were wrapped in moist paper toweling, placed in plastic bags, and stored in the dark at $2^{\circ} \mathrm{C}$ for 7,14 , 28 , and 42 days before planting. Segments were planted horizontally $1.5 \mathrm{~cm}$ deep in moistened vermiculite in plastic trays $(19.5$ by $27.5 \mathrm{~cm}$ ) with adequate drainage. Each group (eight segments from each clone) was subdivided into four lots of two segments. These were distributed among four plant trays so that each tray contained two segments from each clone. The trays were placed in a growth chamber maintained at a $25^{\circ} / 15^{\circ} \mathrm{C}$, $12 / 12$ houx temperature regimen and a $12 / 12$ hour photoperiod and were lightly watered each day. When new trays were added to the growth chamber, they were randomly placed among those already present. Six weeks after the root segments were planted, they were lifted and the number of suckers recorded. The height of the tallest sucker per segment was also noted, along with the occurrence of callus at the ends of the segments.

The storage periods used may not have been long enough to satisfy chilling requirements of root cuttings from dormant trees. Dormant stems generally require more than 2 months of continuous chilling before normal bud break will occur (Barry 1972; Farmer 1968). To make sure that chilling requirements were met, segments from the October collection were also stored for 175 days (October 12 to April 15) and then planted.

\section{RESULTS}

The effect of storing aspen roots at low temperatures on subsequent sucker production is shown in table 1. Storage time had a significant effect on suckering from roots collected in June and August, but not on suckering from those collected in october. Storing June roots for 1 week caused a significant increase (30 percent) in sucker production. Thereafter, increased storage time resulted in only minor changes. Sucker production from August roots significantly decreased (34 percent) during the first 2 weeks of storage and then showed little change with an increase in storage time. Differences among clones were highly significant for all three collection dates. Comparisons among clones are shown in table 2. A nonsignificant clone-storage interaction indicated that the clones responded similarly to treatments. When the analysis was limited to sucker production by the controls, there were significant differences between dates. However, when data from ali treatments were included in a single analysis, differences between dates were not significant. Thus, cold storage generally had an equalizing effect on the number of suckers produced at different seasons, that is, it reduced the seasonal variation in sucker production. Nevertheless, a significant clone-date interaction indicated that some clones showed considerable seasonal variation in sucker production.

The effect of cold storage of aspen roots on subsequent height growth of root suckers is shown in table 3 . Storage on $1 y$ had a significant effect on sucker growth on roots collected in June and August. Sucker heights on June roots were s1ightly increased by 2 weeks of storage. Longer periods of storage caused approximate 1 y 17 percent reduction in growth. On August roots, there were no consistent trends. sucker heights decreased by 15 percent after 1 week of root storage, increased after 2 weeks, 
Table 1.--Effect of time in cold storage on mean number of suckers produced from aspen root outtings $(8$ by 1 to $2 \mathrm{~cm}$ )

\begin{tabular}{|c|c|c|c|c|c|c|c|c|c|c|c|c|c|c|c|c|c|c|c|}
\hline \multirow{3}{*}{ Days } & & \multicolumn{18}{|c|}{ Clone } \\
\hline & : & 1 & $:$ & 2 & $:$ & 3 & $:$ & 4 & $:$ & 5 & $:$ & 6 & & 7 & $:$ & 8 & $: 9$ & $: 10$ & : Mean \\
\hline & $:$ & & : & & $\vdots$ & & : & & $:$ & & $:$ & & $:$ & & $:$ & & $:$ & : & : \\
\hline
\end{tabular}

June Collection

$\begin{array}{rrrrrrrrrrrr}0 & 7.4 & 18.8 & 9.1 & 4.2 & 2.5 & 9.5 & 4.5 & 2.8 & 4.1 & 3.1 & 1_{6.60} \mathrm{~b} \\ 7 & 7.4 & 24.9 & 11.0 & 4.5 & 2.8 & 10.4 & 6.6 & 4.9 & 5.8 & 7.4 & 8.55 \mathrm{a} \\ 14 & 9.4 & 20.0 & 10.6 & 7.1 & 2.0 & 9.1 & 7.8 & 3.0 & 2.9 & 6.9 & 7.87 \mathrm{ab} \\ 28 & 6.9 & 24.6 & 9.5 & 4.8 & 2.8 & 8.2 & 7.0 & 5.5 & 8.9 & 5.9 & 8.40 \mathrm{a} \\ 42 & 4.0 & 22.4 & 10.5 & 3.1 & 1.1 & 11.9 & 4.6 & 3.8 & 4.0 & 8.5 & 7.39 \mathrm{ab} \\ \text { Mean } & 7.05 & 22.20 & 10.20 & 4.80 & 2.30 & 9.85 & 6.00 & 3.90 & 5.10 & 6.45 & 7.78\end{array}$

\section{August Collection}

\begin{tabular}{|c|c|c|c|c|c|c|c|c|c|c|c|}
\hline 0 & 16.1 & 27.9 & 13.2 & 5.9 & 2.1 & 14.1 & 8.1 & 1.8 & 4.2 & 9.1 & $10.26 \mathrm{a}$ \\
\hline 7 & 14.6 & 21.9 & 10.2 & 3.8 & 2.6 & 13.8 & 6.5 & 1.8 & 6.6 & 6.6 & $8.84 \mathrm{ab}$ \\
\hline 14 & 8.6 & 20.2 & 10.1 & 3.9 & 1.5 & 10.9 & 4.6 & 1.4 & 3.0 & 3.9 & $6.81 \mathrm{~b}$ \\
\hline 28 & 14.9 & 16.0 & 13.0 & 3.4 & 1.6 & 11.1 & 3.5 & 2.6 & 5.0 & 7.1 & $7.82 \mathrm{~b}$ \\
\hline 42 & 13.2 & 18.0 & 9.6 & 3.9 & 3.6 & 7.4 & 5.2 & 2.0 & 6.5 & 4.1 & $7.36 \mathrm{~b}$ \\
\hline Mean & 13.50 & 20.75 & 11.20 & 4.10 & 2.35 & 11.35 & 5.45 & 1.85 & 5.15 & 6.20 & 8.19 \\
\hline & \multicolumn{11}{|c|}{ October Collection } \\
\hline 0 & 20.4 & 16.6 & 17.2 & 2.9 & 2.2 & 7.8 & 7.9 & 2.1 & 7.4 & 3.5 & $8.80 \mathrm{a}$ \\
\hline 7 & 14.0 & 22.0 & 21.6 & 4.4 & 2.2 & 11.2 & 7.0 & 2.1 & 7.1 & 0.8 & $9.25 \mathrm{a}$ \\
\hline 14 & 18.8 & 20.4 & 15.4 & 2.5 & 3.0 & 9.1 & 5.6 & 4.0 & 6.8 & 2.9 & $8.84 \mathrm{a}$ \\
\hline 28 & 13.8 & 18.4 & 20.2 & 3.4 & 3.9 & 7.1 & 5.0 & 5.0 & 4,1 & 3.0 & $8.39 \mathrm{a}$ \\
\hline 42 & 14.0 & 18.0 & 22.6 & 8.2 & 4.2 & 8.8 & 4.5 & 4.0 & 7.8 & 2.0 & $9.41 \mathrm{a}$ \\
\hline Mean & 16.15 & 19.05 & 19.50 & 4.30 & 3.20 & 8.85 & 5.95 & 3.55 & 6.65 & 2.60 & 8.98 \\
\hline
\end{tabular}

1 Treatments with no common lettex are significantly different at the 5 percent level.

Table 2.-.-Comparisons among aspen clones in mean number of suckers per outting. clone numbers are in parentheses. Clones are panked in order of decreasing sucker production. Underlined means were not significantiy different ( 5 percent level) from each other.

\begin{tabular}{|c|c|c|c|c|c|c|c|c|c|}
\hline \multicolumn{10}{|c|}{ JUNE } \\
\hline $\begin{array}{r}(2) \\
22.2\end{array}$ & $\begin{array}{r}(3) \\
10.2 \\
\end{array}$ & $\begin{array}{l}(6) \\
9.8 \\
\end{array}$ & $\begin{array}{l}(1) \\
7.1 \\
\end{array}$ & $\begin{array}{r}(10) \\
6.4 \\
\end{array}$ & $\begin{array}{l}(7) \\
6.0 \\
\end{array}$ & (9) & (4) & $\begin{array}{l}(8) \\
3.9\end{array}$ & (5) \\
\hline \multicolumn{10}{|c|}{ AUGUST } \\
\hline $\begin{array}{r}(2) \\
20.8\end{array}$ & $\begin{array}{r}(1) \\
13.5 \\
\end{array}$ & $\begin{array}{r}(6) \\
11.4 \\
\end{array}$ & $\begin{array}{r}(3) \\
11.2 \\
\end{array}$ & $\begin{array}{r}(10) \\
6.2 \\
\end{array}$ & $\begin{array}{l}(7) \\
5.4 \\
\end{array}$ & $\begin{array}{l}(9) \\
5.2\end{array}$ & $(4)$ & 2.4 & $\begin{array}{l}(8) \\
1.8\end{array}$ \\
\hline \multicolumn{10}{|c|}{ OCTOBER } \\
\hline $\begin{array}{r}(3) \\
19.5 \\
\end{array}$ & $\begin{array}{r}(2) \\
19.1 \\
\end{array}$ & $\begin{array}{r}(1) \\
16.2 \\
\end{array}$ & $\begin{array}{l}(6) \\
8.8\end{array}$ & $\begin{array}{l}(9) \\
6.6 \\
\end{array}$ & $\begin{array}{l}(7) \\
6.0 \\
\end{array}$ & 4.3 & $\begin{array}{l}(8) \\
3.6\end{array}$ & $(5)$ & $\begin{array}{r}10) \\
2,6\end{array}$ \\
\hline
\end{tabular}


Table 3.--Effect of time in cold storage on mean height of tallest sucker per aspen root cutting $(8$ by 1 to $2 \mathrm{~cm})$.

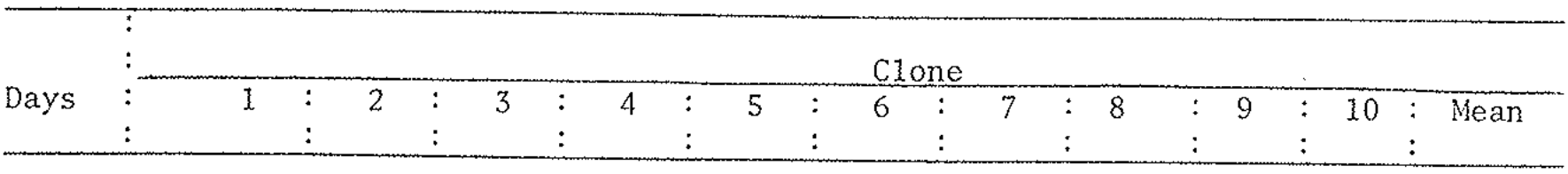

JUNE COLLECTION

$\begin{array}{lllllllllllll}0 & 15.6 & 21.0 & 20.8 & 47.1 & 33.7 & 27.0 & 21.2 & 31.9 & 28.0 & 27.6 & 127.29 & \mathrm{a} \\ 7 & 19.6 & 17.1 & 20.2 & 39.1 & 25.4 & 31.0 & 25.8 & 37.4 & 27.2 & 27.0 & 26.97 & \mathrm{a} \\ 14 & 17.6 & 17.8 & 18.2 & 34.5 & 34.7 & 24.2 & 28.2 & 49.2 & 37.7 & 29.6 & 29.03 & \mathrm{a} \\ 28 & 18.9 & 16.0 & 18.8 & 31.4 & 28.5 & 27.9 & 22.1 & 28.9 & 23.6 & 27.2 & 24.41 & \mathrm{~b} \\ 42 & 18.8 & 13.9 & 13.8 & 30.1 & 32.4 & 22.8 & 22.2 & 31.7 & 28.5 & 26.2 & 23.89 & \mathrm{~b} \\ \text { Mean } & 17.80 & 17.20 & 18.35 & 36.65 & 30.70 & 26.70 & 23.85 & 35.35 & 29.40 & 27.95 & 24.08\end{array}$

\section{AUGUST COLLECTION}

$\begin{array}{lllllllllllll}0 & 23.8 & 21.2 & 27.7 & 39.0 & 44.0 & 32.5 & 26.1 & 34.8 & 28.5 & 24.4 & 29.83 \\ 7 & 20.4 & 20.4 & 19.6 & 31.4 & 38.5 & 23.9 & 20.6 & 40.4 & 24.3 & 22.0 & 25.32 & \mathrm{~b} \\ 14 & 24.2 & 17.9 & 29.7 & 31.3 & 35.8 & 26.2 & 31.8 & 40.3 & 26.7 & 25.8 & 28.49 & \mathrm{a} \\ 28 & 21.6 & 19.4 & 21.9 & 33.1 & 45.4 & 32.0 & 30.8 & 46.4 & 29.3 & 27.6 & 29.72 & \mathrm{a} \\ 42 & 24.5 & 16.5 & 20.7 & 23.1 & 31.9 & 29.9 & 27.6 & 30.6 & 32.1 & 25.3 & 26.11 & \mathrm{a} \\ \text { Mean } & 22.75 & 19.05 & 25.15 & 31.10 & 39.95 & 28.95 & 27.40 & 39.15 & 28.25 & 25.00 & 26.25\end{array}$

\section{OCTOBER COLLECTION}

$\begin{array}{lllllllllllll}0 & 24.2 & 18.6 & 30.1 & 35.4 & 45.0 & 29.9 & 25.1 & 37.8 & 29.2 & 28.1 & 30.23 \text { a } \\ 7 & 24.4 & 23.2 & 25.1 & 27.3 & 44.4 & 35.2 & 28.0 & 41.2 & 32.0 & 36.7 & 31.18 \text { a } \\ 14 & 26.9 & 24.3 & 28.2 & 37.0 & 43.9 & 36.6 & 28.9 & 44.1 & 35.7 & 34.3 & 34.29 a \\ 28 & 25.6 & 19.0 & 24.9 & 33.3 & 44.1 & 40.4 & 26.4 & 45.3 & 30.2 & 24.6 & 31.54 & a \\ 42 & 29.7 & 23.2 & 27.9 & 29.0 & 42.9 & 36.1 & 31.0 & 36.9 & 32.4 & 27.8 & 32.09 & a \\ \text { Mean } & 26.25 & 20.95 & 27.20 & 32.75 & 44.40 & 35.60 & 27.95 & 40.40 & 31.60 & 30.05 & 31.70\end{array}$

1 Treatments with no common letter are significantly different at the 5 percent 1 evel.

and fell again after 6 weeks. Height differences among clones were significant for all three collection dates. Comparisons among clones are shown in table 4. The only roots to show significant clonal differences in response to cold storage were those collected in June. There were significant differences between dates when the analysis was limited to controls. Djfferences increased when all treatments were included in the analysis. A comparison between mean heights showed an increase with each succeding collection date from spring to fall. However, a significant clone-date interaction indicated that not all clones follow this general trend.

The effect of cold storage on callus formation at the ends of root segments is shown in table 5. Storage time significantly affected callus growth at the ends of root segments collected in June and October. Numbers of root ends with callus increased with increasing length of storage time to a peak of 28 days and then decreased. A significant clone-storage interaction was only evident for June roots. Differences among clones were highly significant for each of the three collection dates. Comparisons among clones are shown in table 6. There was little difference between June and August roots in the occurrence of callus. However, on October roots, callus was seven times more frequent than on roots collected earlier. 
Table 4.--Comparisons comong aspen clones in mean height of tallest sucker per cutting. clone numbers are in parentheses. Clones are ranked in order of decreasing sucker heights. Underlined means were not significantly different 15 percent level) from each other.

\begin{tabular}{|c|c|c|c|c|c|c|c|c|c|}
\hline \multicolumn{10}{|c|}{ JUNE } \\
\hline (4) & (8) & (5) & $(9)$ & (10) & $(6)$ & (7) & (3) & (1) & (2) \\
\hline 36.6 & 35.4 & 30.7 & 29.4 & 28.0 & 26.7 & 23.8 & 18.4 & 17.8 & 17.2 \\
\hline \multicolumn{10}{|c|}{ AUGUST } \\
\hline$(5)$ & (8) & (4) & (6) & (9) & $(7)$ & (3) & $(10)$ & (1) & $(2)$ \\
\hline \multirow[t]{2}{*}{40.0} & 39.2 & 31.1 & 29.0 & 28.2 & 27.4 & 25.2 & 25.0 & 22.8 & 19.0 \\
\hline & \multicolumn{9}{|c|}{ OCTOBER } \\
\hline (5) & (8) & $(6)$ & (4) & (9) & (10) & (7) & (3) & (1) & $(2)$ \\
\hline 44.4 & 40.4 & 35.6 & 32.8 & 31.6 & 30.0 & 28.0 & 27.2 & 26.2 & 21.0 \\
\hline
\end{tabular}

Table 5.--Effect of time in cold storage on the number of severed ends of aspen root cuttings $(8 \mathrm{~b}$ y $l$ to $2 \mathrm{~cm}$ ) showing callus fomation (maximum of 16 ends per treatment per clone)

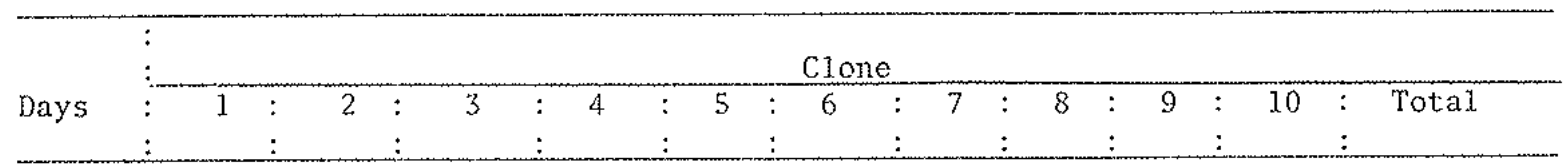

JUNE COLLECTION

$\begin{array}{lllllllllllll}0 & 0 & 0 & 0 & 0 & 0 & 1 & 0 & 0 & 0 & 0 & 1 & 1 \mathrm{c} \\ 7 & 0 & 0 & 0 & 1 & 3 & 1 & 0 & 0 & 0 & 0 & 5 \mathrm{bc} \\ 14 & 0 & 0 & 1 & 2 & 3 & 3 & 0 & 1 & 0 & 0 & 10 \mathrm{ab} \\ 28 & 0 & 0 & 1 & 5 & 0 & 7 & 0 & 2 & 2 & 0 & 17 \mathrm{a} \\ 42 & 0 & 0 & 1 & 4 & 1 & 2 & 0 & 0 & 0 & 0 & 8 \mathrm{abc} \\ \text { Total } & 0 & 0 & 3 & 12 & 7 & 14 & 0 & 3 & 2 & 0 & 41 & \end{array}$

AUGUST COLLECTTON

$\begin{array}{llllllllllll}0 & 1 & 0 & 1 & 4 & 1 & 3 & 0 & 0 & 0 & 0 & 10 \mathrm{a} \\ 7 & 0 & 1 & 0 & 1 & 2 & 6 & 0 & 0 & 0 & 0 & 10 \mathrm{a} \\ 14 & 1 & 0 & 0 & 1 & 2 & 2 & 0 & 0 & 0 & 0 & 6 \mathrm{a} \\ 28 & 1 & 0 & 0 & 3 & 1 & 3 & 0 & 0 & 0 & 0 & 8 \mathrm{a} \\ 42 & 0 & 0 & 0 & 1 & 0 & 1 & 0 & 0 & 0 & 0 & 2 a \\ \text { Total } & 3 & 1 & 1 & 10 & 6 & 15 & 0 & 0 & 0 & 0 & 36\end{array}$

OCTOBER COELECTTON

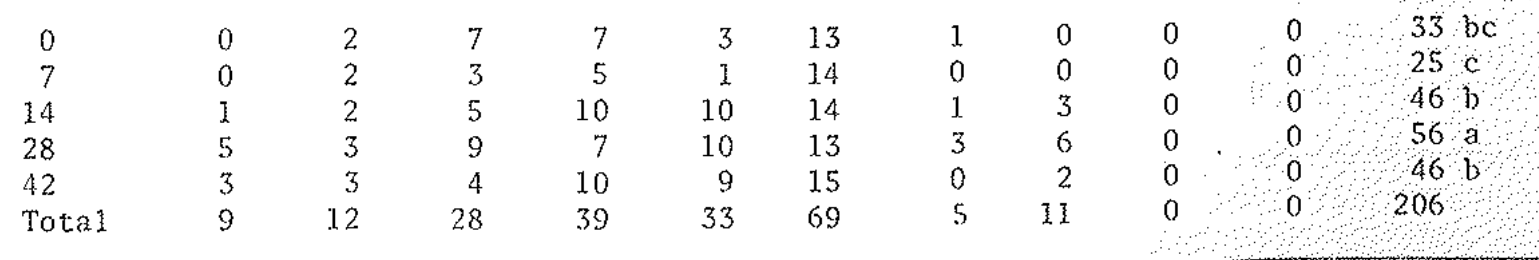

I Treatments with no comon letter are significantly different at the 5 percent 1 evel. 
Table 6.-Comparisons among aspen clones in mean percentage of cutting ends that showed callus formation. Clone numbers are in parentheses. Clones are ranked in order of deoreasing callus formation. Underlined percentages are not significantly different from each other.

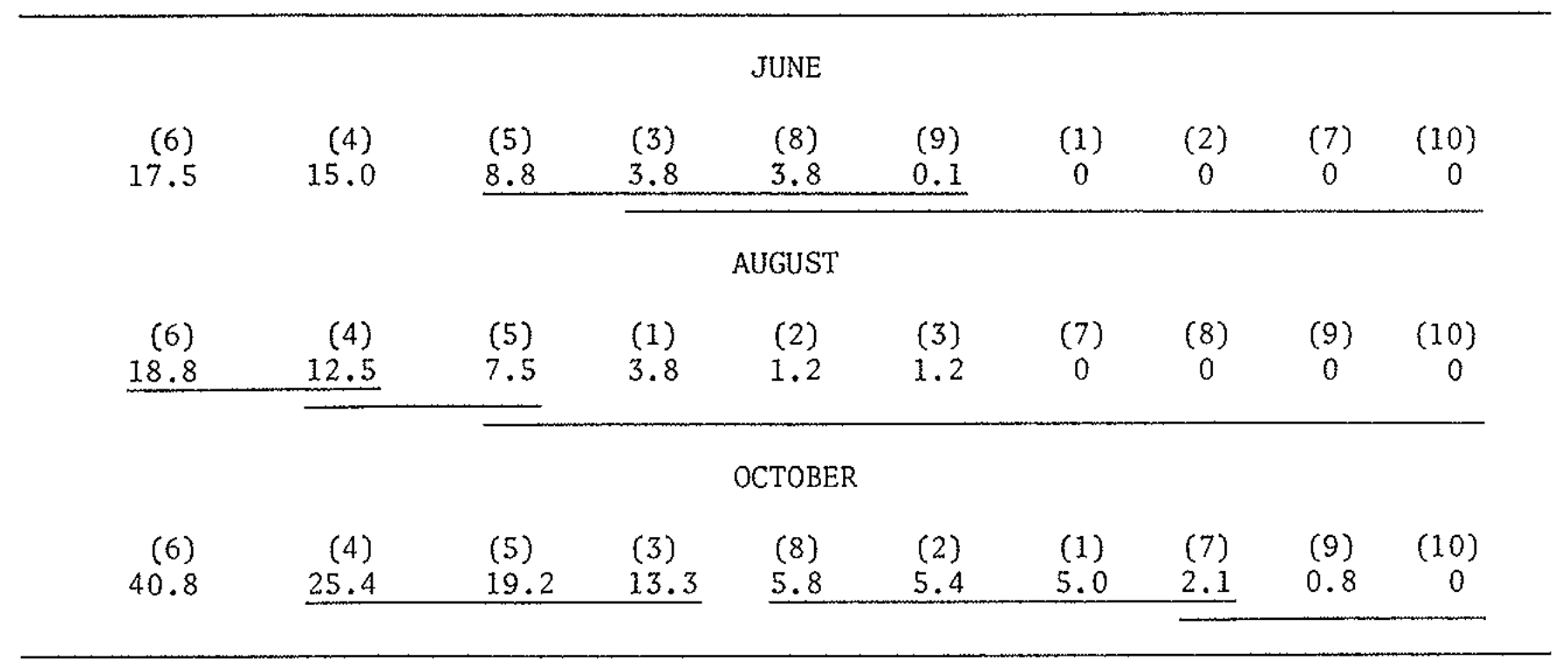

The effect of 175 days of cold storage on subsequent sucker production by root segments collected in Octobex is shown in table 7. Cuttings from only seven clones were used in this experiment. Sucker production from stored roots was not significantly diffexent from those planted immediately after they were collected.

Table 7.--Effect of 175 days' cold storage on mean number of suckers per aspen root cutting ( 8 by 1 to $2 \mathrm{~cm}$ ) for cuttings collected on october 12, 1976, when trees were dormant.

\begin{tabular}{|c|c|c|c|c|c|c|c|c|c|c|c|c|c|c|}
\hline & $\begin{array}{l}: \\
:\end{array}$ & & & & & & & Clone & & & & & & \\
\hline Days & $\vdots$ & 2 & $:$ & 4 & $\begin{array}{l}: \\
: \\
\end{array}$ & 6 & $:$ & 7 & $:$ & 8 & $\begin{array}{l}: \quad 9 \\
\vdots \\
\end{array}$ & $:$ & $\begin{array}{l}: \\
:\end{array}$ & Mean \\
\hline $\begin{array}{r}0 \\
175\end{array}$ & & $\begin{array}{l}16.6 \\
16.8\end{array}$ & & $\begin{array}{l}2.9 \\
5.5\end{array}$ & & $\begin{array}{l}7.8 \\
8.5\end{array}$ & & $\begin{array}{l}7.9 \\
7.1\end{array}$ & & $\begin{array}{l}2.1 \\
5.7\end{array}$ & $\begin{array}{r}7.4 \\
10.4\end{array}$ & $\begin{array}{l}3.5 \\
1.6\end{array}$ & & $\begin{array}{l}6.88 \\
7.94\end{array}$ \\
\hline
\end{tabular}




\section{DISCUSSION}

This study showed that the relative suckering capacity of different aspen clones determined from stored root cuttings is similar to that determined from fresh cuttings. Although cold storage significantly altered the number of suckers produced on cuttings collected on two dates, clones responded similarly to the treatments and therefore the relative differences between clones were not appreciably changed.

Clonal ranking in sucker production showed considerable stability from one date to another (table 2), because most clones showed little seasonal variation in sucker production. However, sucker numbers on the roots of a few clones showed changes of as much as 50 percent from one date to another. Large seasonal variations in sucker production have been reported (Schier 1973b; Tew 1970). Therefore, timing could be critical when evaluating the relative suckering capacities of clones.

During cold storage, sucker production from root segments increased in June and decreased in August; so the seasonal differences between collection dates became insignificant. Inactivation of endogenous growth regulators (inhibitors in June, promoters in August) may be responsible for these changes. The absence of any difference in sucker production between stored and fresh roots in October could mean that hormone concentration in freshly collected roots were at low levels. Schier (1973b) failed to detect auxin, an inhibitor of suckering, in aspen roots collected in October.

Sucker heights showed greater clonal and temporal variation in response to cold storage than sucker numbers. This may have been because numbers of suckers were to a great extent predetermined by the numbers of preexisting shoot primordia (Schiex 1973a), whereas sucker growth was affected by the current physiological conditions of the root. The increase in mean sucker height from June to October is probably caused by the accumulation of carbohydrate reserves in roots that occurs during this period (Schier and Zasada 1973). In spite of clone-storage and clone-date interactions, the rankings of the clones were fairly stable among the three collections.

Callus formation was another index of the effect of cold storage on the physiolog ical conditions of root segments. The frequency of the occurrence of callus at the ends of root segments was more closely related to sucker height than to sucker numbers. The most prolific growth of callus occurred on root segments collected in October when maximum sucker height was also recorded. Clones in which callus formation was common were clones that produced large suckers. The relatively close relationship between sucker height growth and callus development probably was the result of both being dependent on the level of carbohydrate reserves. Significant increase of callus with time in storage suggests that hydrolysis of polysaccharides occurred during cold storage, with corresponding increases in readily available sugars (Robinson and Schwabe 1977; Rutherford and Sewel1 1972).

There was no evidence that adventitious shoot development was inhibited in excised roots of dormant trees. Root cuttings collected in October had a relatively high suckering capacity compared to cuttings collected in June and August and cold storage did not result in a significant increase in sucker production. Schier (in press), however, found that intact roots of dormant trees had cold requirements. When young dormant trees were girdled or decapitated, they produced few suckers. Suckering was prolific in the spring after cold requirements were satisfied by low winter temperatures.

For the person interested in vegetatively propagating aspen, the results of this study indicate that root cuttings from most clones can be safely held for prolonged periods in cold storage. Being able to store roots gives a great deal of flexibility to the propagation of rooted sucker cuttings. For example, roots from a large number 
of clones can be collected at different times, stored, and later planted at the same time. Also, roots can be collected in the fall before snow falls, and stored until lebruary or March when the roots are planted. An early start in propagation makes j.t possible to grow large aspen plants in a single growing season.

\section{PUBLICATIONS CITED}

Barry, W. J.

1972. The ecology of Populus tremuloides, a monogxaphic approach. Ph.D. Thesis, Univ. Calif., Davis. 730 p.

Benson, M. K., and D. E. Schwalbach.

1970. Techniques for rooting aspen root sprouts. Tree Plant. Notes 21(3):12-14.

Farmex, R. E., Jx.

1968. Sweetgum dormancy release: effects of chilling, photoperiod, and genotype.

Physio1. P1ant. 21:1241-1248.

Robinson, J. C., and W. W. Schwabe.

1977. Studies on the regeneration of apple cultivars from root cuttings. If.

Carbohydrate and auxin relations. J. Hort. Sci. 52:221-233.

Rutherford, P. P., and A. P. Sewell.

1972. Carbohydrate changes during cold storage of rhubarb roots, cultivar victoria.

Exp. Hort. 24:37-42.

Sandberg, $D$.

1951. The regeneration of quaking aspen by root suckering. M.F. Thesis, Univ. Minn. $172 \mathrm{p}$.

Schier, G. A.

1973a. Origin and development of aspen root suckers. Can. J. For. Res. 3:45-53.

Schier, G. A.

1973b. Seasonal variation in sucker production from excised roots of Populus tremuloides and the role of endogenous auxin. Can. J. For. Res. 3:459-461.

Schier, G. A.

Root suckering in young aspen, girdled, defoliated, and decapitated at various seasons. In: Proc. 5th N. Am. For. Biol. Workshop, March 13 to 15, 1978, Gainesville, Florida (in press).

Schier, G. A., and J. C. Zasada.

1973. Role of carbohydrate reserves in the development of root suckers in Poputus tremuloides. Can. J. For. Res. 2:243-250.

Starr, G. H.

1971. Propagation of aspen trees from lateral roots. J. For. 69:866-867.

Tew, R. K.

1970. Root carbohydrate reserves in vegetative reproduction of aspen. For. Sci. $16: 318-320$.

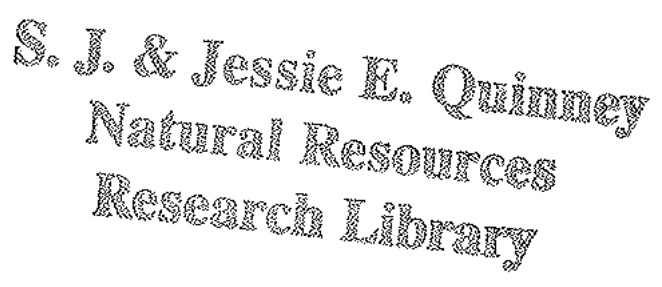

